\title{
Articles
}

\section{In situ Photoacoustic Study of Water Gas Shift Reaction over Magnetite/Chromium Oxide and Copper/Zinc Oxide Catalysts}

\author{
In-Sik Bỵun, Ok-Lim Choi, Joong-Gill Choi, and Sung-Han Leè. \\ Depatment of Chemisty, Tonse Lhiversity, Seoul 20-749, Korea \\ Department of Chemistin, Fonsei Thiversity, Honju 220-710, Korea \\ Received April 16,2002
}

\begin{abstract}
Kinetic studies on the water-gas shift reaction catalyzed by magnetite/chromium oxide and copper/zinc oxide were carried out by using an in sim photoacoustic spectroscopic technique. The reactions were performed in a closed-circulation reactor system using a differential photoaconstic cell at total pressure of 40 lor in the temperature range of 100 to $350^{\circ} \mathrm{C}$. The $\mathrm{CO}_{2}$ photoacoustic signal varying with the concentration of $\mathrm{CO}_{2}$ during the catalytic reaction was recorded as a function of time. The time-resolved photoacoustic spectra obtained for the initial reaction stage provided precise data of $\mathrm{CO}_{2}$ formation rate. The apparent activation energies determined from the initial rates were $74.7 \mathrm{~kJ} / \mathrm{mol}$ for the magnetite/chromium oside catalyst and 50.9 $\mathrm{kJ} / \mathrm{mol}$ for the copper/zinc oxide catalyst. To determine the reaction orders, partial pressures of $\mathrm{CO}(\mathrm{g})$ and $\mathrm{I}_{2} \mathrm{O}(\mathrm{g})$ in the reaction mixture were varied at a constant total pressure of 40 'lorr with $\mathrm{N}_{2}$ buffer gas. For the magnetite/chromium oxide catalyst, the reaction orders with respect to $\mathrm{CO}$ and $11_{2} 0$ were deternined to be 0.93 and 0.18 , respectively. For the copper/zinc oxide catalyst the reaction orders with respect to 0 and $11_{2} 0$ were detemined to be 0.79 and 0 . respectively:
\end{abstract}

Key Words : Photoacoustic spectroscopy, Water gas shilt reaction, Magnetite/chromia catalyst, Copper/anc oxide calalys

\section{Introduction}

The water gas shift reaction (WGSR), $\mathrm{CO}+\mathrm{H}_{2} \mathrm{O} \rightleftharpoons \mathrm{CO}_{2}$ $+\mathrm{H}_{2}$. has been most frequently used to increase the $\mathrm{H}_{2}$ content of synthesis gas through the reaction of $\mathrm{CO}$ with steam. When carbonaceous materials react with steam at high temperature. $\mathrm{H}_{2} . \mathrm{CO} . \mathrm{CO}_{2}$ and $\mathrm{H}_{2} \mathrm{O}$ are produced as major products of which composition can be adjusted via the WGSR to give lydrogen gas for synthesis gas with the various $\mathrm{H} / \mathrm{CO}$ ratios appropriate to the production of hydrocarbons or alcohols. etc. Therefore. the WGSR is also important in the production of gaseous and liquid hydrocarbons from coal and natural gas. It has been known that metals and metal oxides exhibit catalytic activities for the WGSR ${ }^{1.2}$ Magnetite-based catalysts and copper-based catalysts are known to be active cataly sts for the WGSR. Magnetite/ chromium oxide catalyst operates at higher temperatures $\left(\geq 350^{\circ} \mathrm{C}\right.$ ). while copper/zinc oxide/alumina catalyst operates at lower temperatures $\left(200-300^{\circ} \mathrm{C}\right)$ but is highly sensitive to sulfur poisoning. The kinetics of the WGSR over the highand low-temperature catalysts have been studied widely by several groups. ${ }^{3}$ However. there are still some disagreements on the reaction mechanisms and the kinetic parameters such as the reaction orders. the rate constant, and the activation

"Corresponding Authors. Joong-Gill Choi(lax: +82-2-364-7050, e-mail: jgchoi àalchemy yonsei.ac.kr) energy.

A large fraction of catalytic research involves the investigation of kinetic phenomena. i.e. quantitative studies of reaction rate and factors which are influencing the rate. An accurate description of the reaction rate can be obtained from a rate law which is essential in the calculation of a reactor design. Although it is difficult to determine the accurate mechanism from an empirical kinetic expression. such empirical kinetic expression may be helpful to understand the catalytic reaction mechanisim. The most important consideration in the kinetic experiments is to measure the concentration of reactants or products of interest as a function of time. To measure the concentration, absorption spectroscopy techniques have been generally used. However. their sensitivities may be diminished due to the difficulty in precise measurements of the difference between the incident and the transmitted intensities of radiation. The photoacoustic spectroscopy (PAS) is based on a direct measurement of acoustic waves generated owing to the absorption of optical energy. The principle of this effect is quite simple: when a material absorbs a modulated laser beam and generates heat periodically. a photoacoustic signal is created. The dependence of the photoacoustic signal on the optical absorption coefficient and the light-into-heat conversion efficiency allows one to obtain directly the nonradiative energy conversion efficiency, i.e. the photoinduced energy conversion process. Its selectivity and extremely low molecular gas level detec- 
tion limit enable us to obtain a signal with enough intensity for even time-resolved experiments. ${ }^{4-}$ In addition to the inherent high sensitivity of the photoacoustic detection. a further advantage of this technique can be found in the capability of the elimination of any soplisticated sampling tecluiques which are inevitable in the comventional techniques such as MS or GC. The photoacoustic spectroscopy is thus believed to be a suitable technique for the in situ experiment of a catalytic reaction because it can directly measure the absorption characteristics of the samples of interest. ${ }^{7.8}$

In recent. we have studied the WGSR over the vacuumactivated ferric oxide catalyst and reported that a $\mathrm{CO}_{2}$ laserbased photoacoustic spectroscopy was applicable to the kinetic study of WGSR ${ }^{9}$ ln this work. we performed kinetic studies on the WGSR over $\mathrm{Fe}_{3} \mathrm{O}_{1} / \mathrm{Cr}_{2} \mathrm{O}_{3}$ and $\mathrm{Cu} / \mathrm{ZnO}$ catalysts by using a photoacoustic spectroscopy technique. To measure the temporal change in the concentration of $\mathrm{CO}_{2}$ for the WGSR, a photoacoustic detection techuique with a suitable differential photoacoustic cell was employed. The measurements were performed at low pressure so that the teclunique provided precise kinetic data for the initial stage characterized by ligh reaction rates. The kinetic data obtained were then compared with those of other investigators and active sites were discussed from the results.

\section{Experimental Section}

Figure 1 shows an experimental arrangement for the photoacoustic detection method employed in this work. The kinetic study was carried out in a closed-circulation fixedbed type microreactor made of quartz with a volume of approximately $40 \mathrm{~cm}^{3}$. The microreactor was placed in the electric fumace maintained at a constant temperature within $0.5 \mathrm{~K}$ by an electronic controller with a $\mathrm{K}$-ty pe themocouple. The reactor was directly connected to a photoacoustic cell by approximately $15 \mathrm{~cm}$ away with an adjoining tube. The differential photoacoustic cell consisted of two compartments: i.e. a reference cell and a sample cell. separated from each other by a ZnSe window. Each photoacoustic cell. in which $\mathrm{ZnSe}$ windows formed the end of the cell. was a Helmholtz resonator of $1.9 \mathrm{~cm}$ in diameter and $3.3 \mathrm{~cm}$ in length with an adjoining tube of $1.0 \mathrm{~cm}$ in diameter and $10 \mathrm{~cm}$ in length. A closed volume of gas in the Helmholz resonator behaves as a spring when acoustically excited. and the gas inside an adjoining tube acts a mass attached to the spring. Due to the viscous drag of the gas motion inside the tube. the resonator

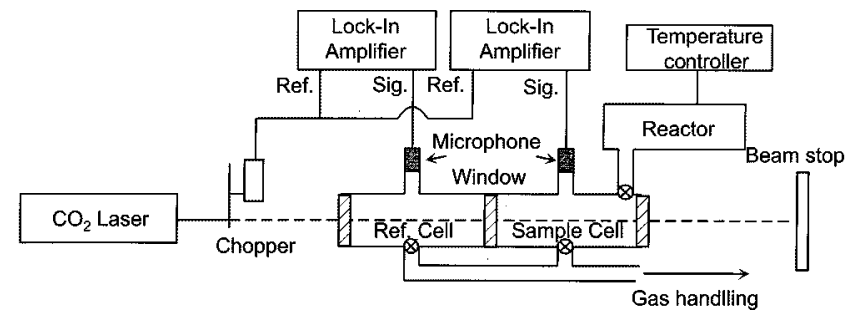

Figure 1. An experimental selup for the photoacoustic delection methos. behaves as a damped hamonic oscillator. Thus an acoustic resonance can be obtained at relatively low frequencies even when the volume of the detection cell is small.

The output beam of a cw $\mathrm{CO}_{2}$ laser (Synrad Series 48-128) operating in multiline of $10.6 \mu \mathrm{m}$ was modulated at 25 $\mathrm{Hz}$. The nonresonance condition was used in order to prevent any change of the signal due to the variation in the resonance frequency followed by the temperature cliange in the Helmholtz resonator. The photoacoustic signals from the microphones attached at the reference cell (signal A) and the sample cell (signal B) connected to the microreactor were detected by a lock-in amplifier (Stanford Research Systems Model SR850). and the signal ratio ( $\mathrm{A} / \mathrm{B})$ was recorded by a personal computer as a function of time.

Kinetic studies on the water-gas shift reaction were performed for two commercial catalysts, magnetite/cluromium oxide (CCE C 12) and copper/zinc oxide catalysts (ICI 52-1). Powdered catalysts of $80-100$ mesh in the particle size were used in this experiment and the BET surface areas determined by the liquid nitrogen method were $57.9 \mathrm{~m}^{2} / \mathrm{g}$ and 84.6 $\mathrm{m}^{2} / \mathrm{g}$ for magnetite/chromium oxide cataly st and copper/zinc oxide catalyst. respectively: Prior to the each measurement. magnetite/chromium oxide catalyst was exacuated in sinu at $400^{\circ} \mathrm{C}$ and $1 \times 10^{-5}$ Torr for $3 \mathrm{~h}$ and copper/zine oxide catalyst was treated $i n$ situ in a flow of $\mathrm{H}_{2}(5 \%) /$ Ar mixture at $200^{\circ} \mathrm{C}$ for $3 \mathrm{~h}$. After the pretreatment, the reactor was cooled to room temperature where $N_{2}$ gas was passed to remove oxygen gas remaining in the reactor. The reaction mixture was then admitted into the microreactor at given temperature of the reaction. The purity of $\mathrm{CO}$. $\mathrm{CO}_{2}$. and $\mathrm{N}_{2}$ was greater than $99.99 \%$. Water vapor was generated from the deionized water by heating it at an appropriate temperature to obtain a desired vapor pressure. To avoid the condensation of water vapor. all the lines were heated by using a heating band. A capillary silicon oil manometer (1/13 Torr precision) and a pirani gauge were used to monitor the gas pressure. The reference cell was filled with a gaseous mixture of $\mathrm{CO}_{2}\left(0.2\right.$ Torr) and $\mathrm{N}_{2}$ (39.8 Torr). The sample cell was colmected to the microreactor loaded with the catalyst. in which the total pressure of gaseous mixture of $\mathrm{CO}$ and water vapor was kept at 40 Torr with $\mathrm{N}_{2}$ buffer gas.

The measurements were carried out in the temperature range of $200-350^{\circ} \mathrm{C}$ for the magnetite/chromium oxide catalyst and of $100-220^{\circ} \mathrm{C}$ for copper/zinc oxide catalyst. A blank experiment in the absence of the catalyst showed that no detectable amount of $\mathrm{CO}_{2}$ was fomed in the temperature range of $100-350^{\circ} \mathrm{C}$. To identify the phase of the catalysts. X-ray powder diffraction analysis (Philips pw 1710 XRD) was performed. X-ray photoelectron spectroscopic analysis (Marker SSI 2803-S ESCA) was also carried out to innestigate the oxidation state of each element on the catalyst surface. The ratios of $\mathrm{Fe} / \mathrm{Cr}$ in the magnetite/chromium oxide catalyst and $\mathrm{Cu} / \mathrm{Zn}$ in the copper/zinc oxide catalysts were determined by using ICP-AES (inductively coupled plasma-atomic emission spectroscopy) technique. The ratios of $\mathrm{Fe} / \mathrm{Cr}$ and $\mathrm{Cu} / \mathrm{Zn}$ in wt.\% were found to be 18.0 and 0.79 , respectively. 


\section{Results and Discussion}

The photoacoustic signal is generally affected by various conditions, such as the exeitation wavelength and the power of light souree, the chopping frequency, the physical properties of analytes, and the sensitivity of microphone. ${ }^{+}$In addition, the photoacoustic signal is directly proportional to the concentration of analyte in a given condition, allowing this method to be applicable for the quantitative analysis. In this experiment, the signal dependence on the power of incident beam showed a linear relation in the power range from 1 to $8 \mathrm{~W}$ of the $\mathrm{CO}_{2}$ laser. Because the sensitivity of the photoacoustic signal inereases with decreasing the total pressure of gas medium, it is desirable to keep the gas pressure as low as possible. Therefore, the total pressure of gascous reactants in the microreactor, filled with $\mathrm{N}_{2}$ as a buffer gas, was kept at 40 Torr. In the present work, the $\mathrm{CO}_{2}$ PAS signal was linearly varied with the partial pressure of $\mathrm{CO}_{2}, \mathrm{PcO}_{2}$, below 20 Torr. Aceordingly, the measurements of the photoacoustic signal in time relative to the initial condition directly rellected the change of the $\mathrm{PCO}_{2}$ in the mieroreactor during the catalytic reaction.

Magnetite/Chromium Oxide Catalyst. Figure 2 illustrates the variations of the $\mathrm{CO}_{2}$ photoacoustic signals with time-onstream at various temperalures when the $\mathrm{CO} / \mathrm{I}_{2} \mathrm{ONN}_{2}(5 / 10 /$ 25 Torr) mixture was introduced over the magnetilechromium oxide catalyst, in which the rate of $\mathrm{CO}_{2}$ formation in-

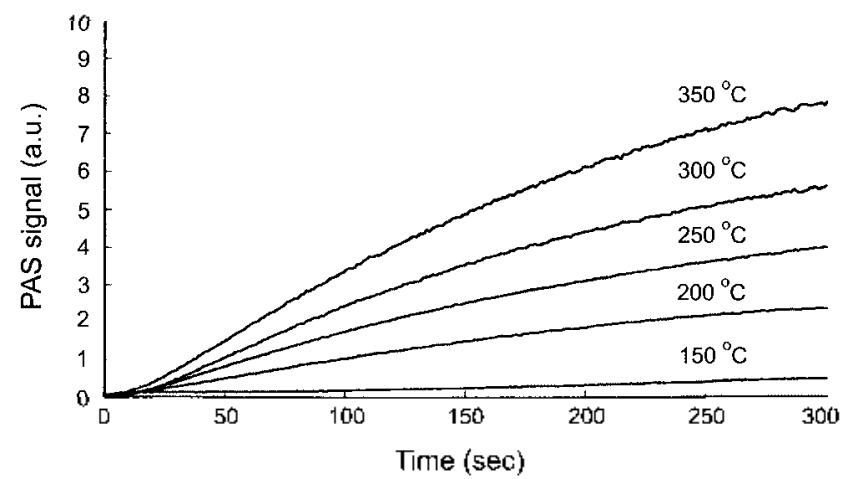

Figure 2. $\mathrm{CO}_{2}$ photoacoustic signals as a lunction of time at various temperatures for the water-gas shift reaclion over magnetice/ chromium oxide catalyst.

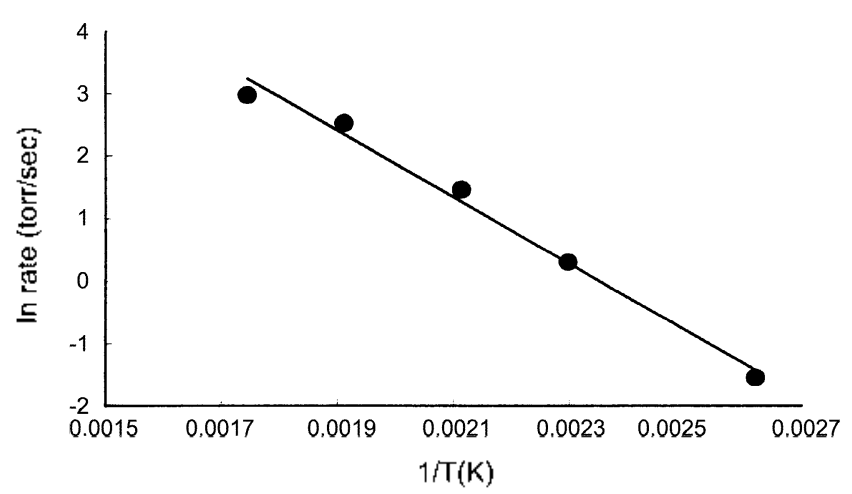

Figure 3. Ln rate $v s$. I/T for the water-gas shift raction over magnetite/chromium oxjde catalyst. creased with increasing temperature in the range of 150-350 "C. The rates of $\mathrm{CO}_{2}$ formation were typically estimated from the slope of each PAS curve in the temporal range of $20-50 \mathrm{sec}$. Figure 3 shows the rates of $\mathrm{CO}_{2}$ formation plotted as a lunction of temperature according to the Arrhenius equation so that the apparent activation energy detemined from the slope was $74.7 \mathrm{~kJ} / \mathrm{mol}$. The reported activation energies for the WGSR over magnetite/chromium oxide catalyst are in the range from 40 to $150 \mathrm{~kJ} / \mathrm{mol} .^{10.11}$ The lower activation energy obtained here. $74.7 \mathrm{~kJ} / \mathrm{mol}$, is believed to be caused by diffusional limitations in the eatalyst particles as explained by Keiski et $a l^{10}$ To investigate the reaction orders with respect to $\mathrm{CO}(\mathrm{g})$ and $\mathrm{I}_{2} \mathrm{O}(\mathrm{g})$. the $\mathrm{CO}_{2}$ pholoacoustic signals were measured at various partial pressures of $\mathrm{CO}$ and $\mathrm{I}_{2} \mathrm{O}$. Figure 4 demonstrates the $\mathrm{CO}_{2}$ photoacoustic signals measured at various Pco's at $300^{\circ} \mathrm{C}$ and the reaction order with respect to $\mathrm{CO}$ determined from the reaction rates is 0.93 . Figure 5 shows the $\mathrm{P}_{\mathrm{II}_{2} \mathrm{O}}$ dependence of the $\mathrm{CO}_{2}$ photoacoustic signal measured at $300^{\circ} \mathrm{C}$ and the reaction order calculated from the reaction rates is 0.18 . Figure 6 presents the $\mathrm{Fe}\left(2 \mathrm{p}_{\mathrm{i} 2}\right)$ XPS spectrum for the vacuum-treated magnelite/chromium oxide catalyst, where the $\mathrm{Fe}\left(2 \mathrm{p}_{3,2}\right)$ XPS peak could be resolved into two peaks a1 711.2 and $713.5 \mathrm{cV}$.

Reaction mechanism for the water-gas shift reaction have been sludied by many investigators during the past live decades and the reaction mechanisms proposed generally

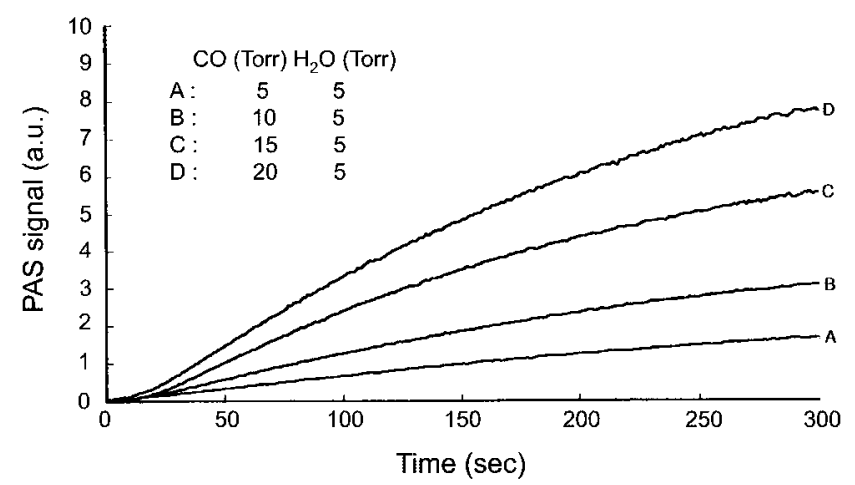

Figure 4. $\mathrm{P}_{\mathrm{CO}}$ dependence of $\mathrm{CO}_{2}$ photoacoustic signal for the water-gas shift reaction over magnetite/chromium oxide catalyst at $300^{\prime \prime} \mathrm{C}$.

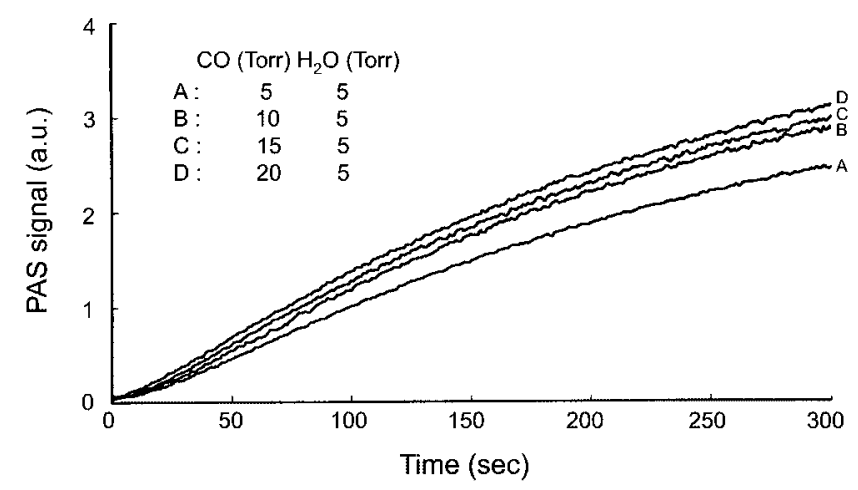

rigure 5, $\mathrm{P}_{\mathrm{H} \text { O }}$ dependence of $\mathrm{CO}_{2}$ photoacoustic signal for the water-gas shift reaction over magnetite/chromium oxide catalyst at $300^{\circ} \mathrm{C}$. 


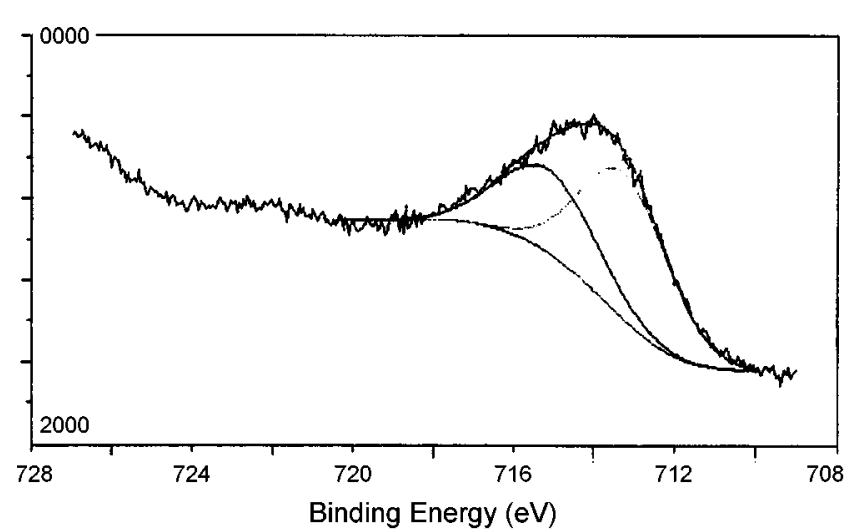

Figure 6. $F\left(2 p_{i_{2}}\right)$ XPS spectrum of the vacuum-treated magnetiti chromium oxide calalysis.

fall into two types: an associative mechanism and a regenerative mechanism. The associative mechanism includes the formation of an intermediate (e.g., formates) from the reactants on the catalyst surlace and the regenerative mechanism includes the participation of surface oxygens in the catalytic reaction. "It is now generally aceepted that the regenerative mechanism is dominant on $\mathrm{Fc}_{3} \mathrm{O}_{4} / \mathrm{Cr}_{2} \mathrm{O}_{3}$ calalyst. It has been known that in $\mathrm{Fe}_{3} \mathrm{O}_{4} / \mathrm{Cl}_{2} \mathrm{O}_{3}$ catalyst $\mathrm{Fe}_{3} \mathrm{O}_{4}$ is an active phase and $\mathrm{Cr}_{2} \mathrm{O}_{3}$ prevents the thermal sintering of neighbouring magnetite particles. ${ }^{3}$ Magnetite is known to be an inverse spinel at room temperature, i.e. one-cighth of tetrahedral sites and one-fourth of the octahedral sites are occupied by trivalent Fe-ions while one-fourth of the octahedral sites are occupied by divalent Fe-ions. The distribution of the divalent and trivalent Fe-ions are known to be randomized over the occupied tetrahedral and octahedral sites at high temperatures. ${ }^{12}$ Because each oxygen ion is coordinated to three octahedral cations and one tetrahedral cation. the climination of the oxygen ion from the surface and the oxygenation of the surface are connected with octahedral cations. Tinkle and Dumesic suggested that CO interacts with an $\mathrm{M}-\mathrm{O}$ pair site with an active oxygen and $\mathrm{I}_{2} \mathrm{O}$ interacts with an $\mathrm{M}-\mathrm{O}$ pair site with an adjacent vacant site. ${ }^{13}$ If CO reacts with an oxygen ion on the surface to form $\mathrm{CO}_{2}$, the reactions can be written as

$$
\begin{gathered}
\mathrm{CO}+\mathrm{O}_{\circ} \text { (latt) } \rightleftharpoons \mathrm{CO}_{2} \text { (ads) } \\
\mathrm{CO}_{2} \text { (ads) } \rightleftharpoons \mathrm{CO}_{2} \text { (g) }
\end{gathered}
$$

When $\mathrm{CO}_{2}$ is desorbed from the surface, the oxygen vacancy $\left(\mathrm{V}_{0}{ }^{x}\right)$ can be formed on the sutface. Since the oxygen vacancy can act as an electron donor, it is feasible that $\mathrm{l}_{2} \mathrm{O}$ being a potential oxidant is chemisorbed on the oxygen vacancy. The reactions can be expressed as

$$
\begin{gathered}
\mathrm{H}_{2} \mathrm{O}(\mathrm{g})-\mathrm{V}_{\mathrm{o}} \rightleftharpoons \mathrm{OH}^{-} \text {(ads) }-\mathrm{H}^{\prime} \text { (ads) } \\
\mathrm{OH}^{-} \text {(ads) }-\mathrm{H}^{\prime} \text { (ads) } \rightleftharpoons \mathrm{H}_{2}(\mathrm{~g})-\mathrm{O}_{0} \text { (latt) }
\end{gathered}
$$

The reactions mean that the catalyst surface is reduced by $\mathrm{CO}$ and re-oxidized by $\mathrm{H}_{2} \mathrm{O}$. The latice oxygen is subsequently reduced by $\mathrm{CO}$ thereby producing $\mathrm{CO}_{2}$ to complete the catalytic cycle.

The isolope exchange study on the WGSR over magnetite/ chromium oxide catalyst by Tinkle and Dumesic ${ }^{13}$ showed that the rates of $\mathrm{CO}$ adsorption and $\mathrm{CO}_{2}$ desorption were slow. The rate of $]_{2} \mathrm{O}$ adsorption was found to be last while the rate of $\mathrm{Il}_{2}$ desorption was slow. They derived a rate expression and predicted the reaction rates by using the kinclic data of Oki ef al. ${ }^{14}$ They also showed that the reaction rates predieted from the reaction model were in good agreement with those calculated from the rate law as lit by Bohlbro ${ }^{15}$ which was expressed in the form

$$
\text { rate }-k \mathrm{PCO}^{0.9} \mathrm{PlI}_{2} \mathrm{O}^{0.25} \mathrm{PCO}_{2}{ }^{0.65}
$$

Keiski ef $a l^{2}$ performed a kinetic sludy on the WGSR over $\mathrm{Fe}_{3} \mathrm{O}_{4} / \mathrm{Cr}_{2} \mathrm{O}_{3}$ catalyst at atmospheric pressure. They found that the power-law rate model with concentration exponents of $\mathrm{CO}$ and $\mathrm{I}_{2} \mathrm{O}$ close to $\mathrm{I}$ and 0 , respectively, provided the best results. The stationary kinetic sludy on the WGSR over $\mathrm{Fe}_{3} \mathrm{O}_{4} / \mathrm{Cr}_{2} \mathrm{O}_{3}$ catalyst showed that the reaction orders with respect to $\mathrm{CO}$ and $\mathrm{I}_{2} \mathrm{O}$ were approximately 1 and 0.5 , respectively. ${ }^{10}$ The reaction orders determined in this work were 0.93 with respect to $\mathrm{CO}$ and 0.18 10 $\mathrm{I}_{2} \mathrm{O}$. The 0.93 order to CO was in good agreement with that reported. ${ }^{10}$ On the other hand, the 0.18 -order with respect to $\mathrm{H}_{2} \mathrm{O}(\mathrm{g})$ was found to be close to the 0.25 -order reported by Bohlbro ${ }^{15}$ and Tinkle et al., ${ }^{1.3}$

Copper/Zinc Oxide Catalyst. Figure 7 shows variations of the $\mathrm{CO}_{2}$ photoacoustic signals with time-on-stream at various temperatures when the reaction mixture $(\mathrm{CO} /]_{2} \mathrm{O}$

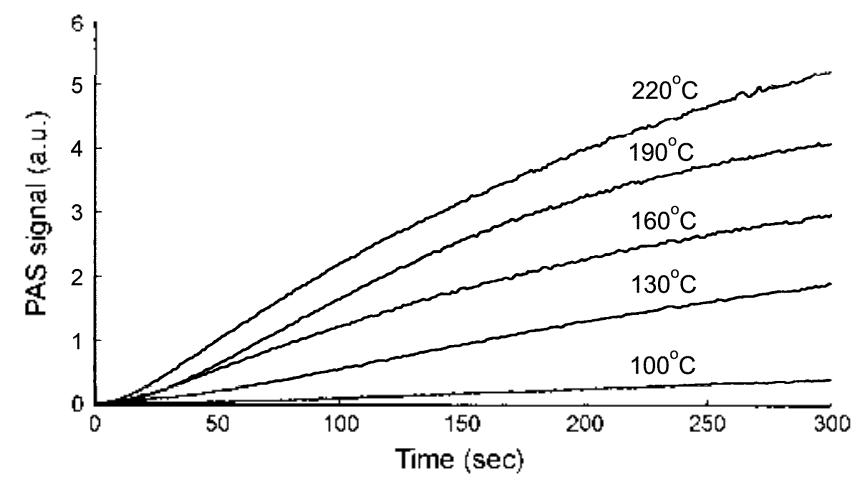

Figure 7. $\mathrm{CO}_{2}$ photoacoustic signals as a function of time at various lemperatures for the water-gas shift reaction over copper/zinc oxide catalyst.

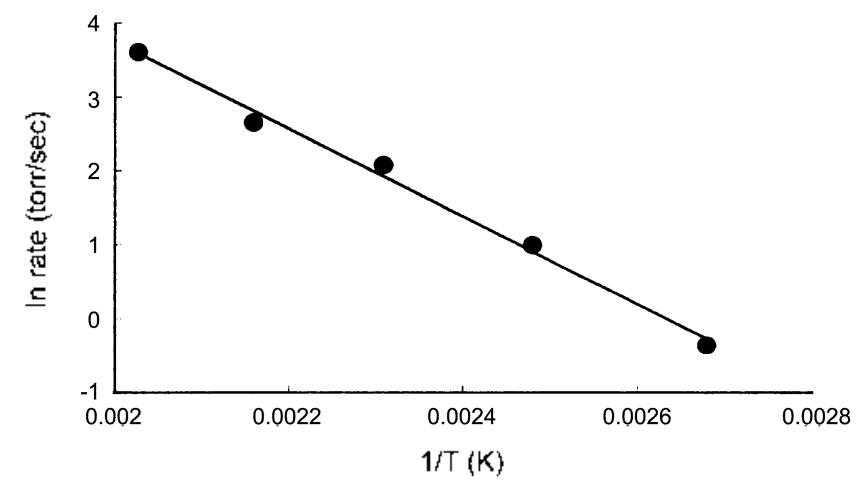

Figure 8. In rate vs, $1 / 1$ for the water-gas shift reaction over copper/zinc oxide catalyst. 
$\mathrm{N}_{2}-5 / 10 / 25$ Torr) was introduced over the copper/zinc oxide catalyst. Figure 8 shows the rates of $\mathrm{CO}_{2}$ formation plotted as a function of temperature in the range of $100-220^{\prime \prime} \mathrm{C}$. According to the Arthenius equation the apparent activation energy determined from the slope was $50.9 \mathrm{~kJ} / \mathrm{mol}$. Figure 9 illustrates the $\mathrm{P}_{\mathrm{Co}}$ dependence of the $\mathrm{CO}_{2}$ photoacoustic signal measured at $200^{\circ} \mathrm{C}$. The $\mathrm{CO}_{2}$ formation rate increased with increasing the $\mathrm{PCO}_{\mathrm{CO}}$ and the reaction order to $\mathrm{CO}$ detemined from the reaction rates was 0.79 . Figure 10 shows the $\mathrm{P}_{112 \mathrm{O}}$ dependence of the $\mathrm{CO}_{2}$ photoacoustie signal measured at $200^{\circ} \mathrm{C}$ and the reaction order with respect to

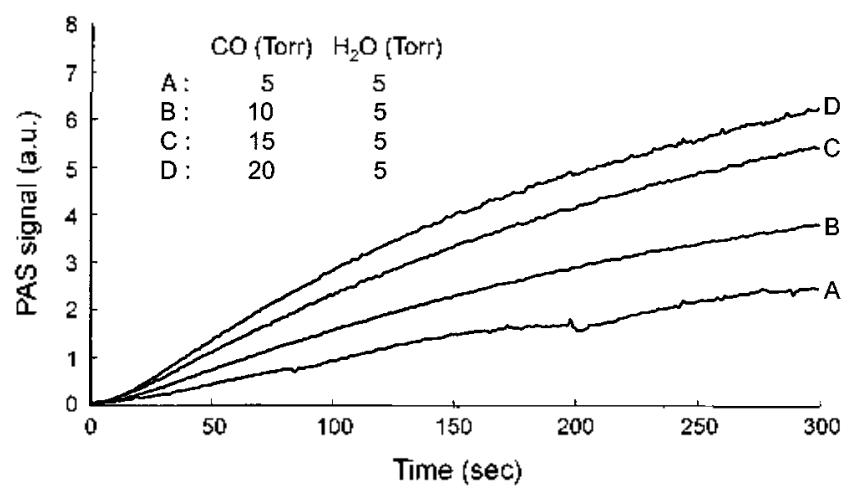

Figure 9. Pro dependence of $\mathrm{CO}_{2}$ photoacoustic signal for the water-gas shift reaction over copperizine oxide cataly st at $200^{\circ} \mathrm{C}$.

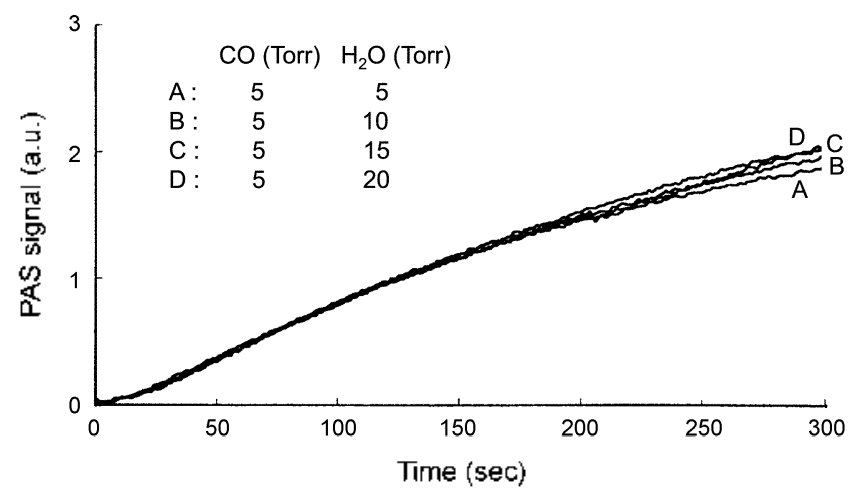

Figure 10. $P_{1[0,0}$ dependence of $\mathrm{CO}_{2}$ photoacoustic sienal for the waler-gass shili reaction over copper/ginc oxide calaly sl al $200^{\circ} \mathrm{C}$.

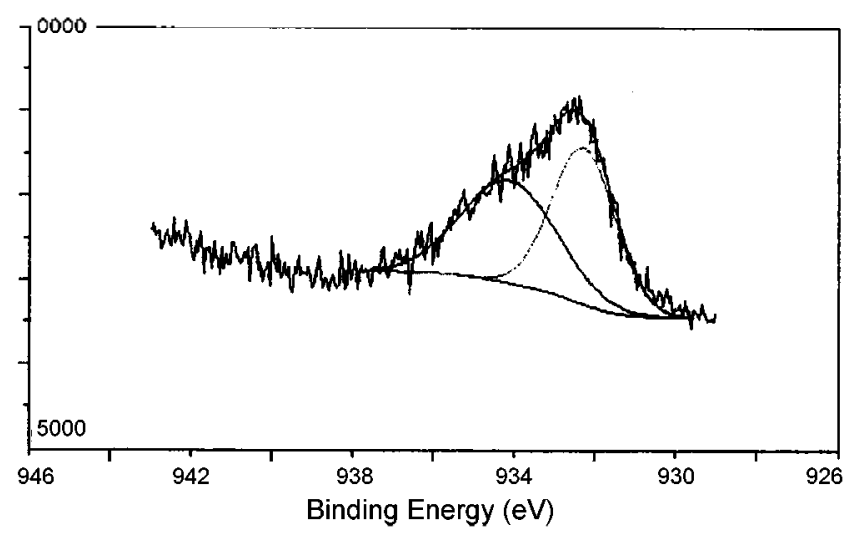

Figure 11. Cu(2 $\left.2 p_{12}\right)$ XPS spectrum of the $\mathrm{H}_{2}$-treated copperizinc oxide catalyst.
$\mathrm{I}_{2} \mathrm{O}$ determined from the reaction rates was found to be zero. Figure 11 presents the Cu(2pse) XPS spectrum for the $\mathrm{I}_{2}$-treated copper/zinc oxide calalyst, in which the spectrum shows a maximum at $932.1 \mathrm{cV}$ and a shoulder at $934.1 \mathrm{eV}$. The higher binding energy is due to $\mathrm{Cu}^{2-}$ and the lower binding energy is duc to $\mathrm{Cu}^{0}$ or $\mathrm{Cu}^{1+}$. It is not clear to distinguish the lower binding energy corresponds to $\mathrm{Cu}^{\circ}$ or $\mathrm{Cu}^{1-}$, because the binding energy of $\mathrm{Cu}^{0}$ is close to that of $\mathrm{Cu}^{\mathrm{I}}$.

Copper-based catalysts have been studied for the lowtemperature WGSR by many investigators. Nevertheless there are only a few reports of kinetic studies on the WGSR over copper-based catalysts. There still exists a controversy aboul the nature of the active site in copper-based catalyst for the WGSR. In the copper/zine oxide eatalysts, it is generally agreed that zinc oxide acts only as a support for the dispersed copper. ${ }^{16}$ Grenoble ef al. ${ }^{1}$ performed kinctic studies on the WGSR over various metal/alumina catalysts. They proposed a reaction sequence including formic acid as an intermediate in order to account for the apparent bifunctionality of the supported metal catalysts. On the assumption that the adsorption of $\mathrm{CO}$ onto metal sites was nondissociative and the adsorption of water on metal sites was dissociative, they derived a power rate law given in the form

$$
r a t e^{\prime}-k P()^{y} P_{\mathrm{H}-x)}^{(1-x)}
$$

They also showed that the kinetic data measured for the WGSR over various metal alumina catalysts were well fitted inte the rate law. For instance, the reaction orders for the WGSR over the $10 \% \mathrm{Cu} / \mathrm{Al}_{2} \mathrm{O}_{\text {s }}$ calalyst were 0.30 with respect to $\mathrm{CO}$ and 0.38 10 $\mathrm{I}_{2} \mathrm{O}$. following the $\mathrm{Eq}$. (6) well. In this work, however the reaction orders with respect $10 \mathrm{CO}$ and $\mathrm{I}_{2} \mathrm{O}$ were 0.79 and 0 . respectively, which were not litted into the Eq. (6), implying that $\mathrm{CO}$ and $\mathrm{I}_{2} \mathrm{O}$ were not competitively adsorbed on the copper metal.

The change in the standard free energy for the reaction. $2 \mathrm{Cu}(\mathrm{s})+\mathrm{II}_{2} \mathrm{O}(\mathrm{g}) \rightarrow \mathrm{Cu}_{2} \mathrm{O}(\mathrm{s})+\mathrm{IJ}_{2}(\mathrm{~g})$, is $20.6 \mathrm{~kJ} / \mathrm{mol}$, indicaling that the oxidation of copper is unlikely proceded in the presence of water. Nevertheless, it has been found that the copper metal can be oxidized in the presence of steam at low temperatures. In this respect. the WGSR over Cu-based catalysis has been the subject of considerable study. To explain the WGSR over copper-based catalysts, a surface redox mechanism has been suggested. ${ }^{17}$ In this mechanism, the initial dissociation of $\mathrm{I}_{2} \mathrm{O}$ is found to be the ratedetermining step, in which water dissociates completely to an oxygen adatom (O(ads)) and $]_{2}$. Although there is still much debate arisen on the ability of copper metals for the dissociative chemisorption of $\mathrm{H}_{2} \mathrm{O}$, several investigators have provided evidences for the dissociation of $\mathrm{J}_{2} \mathrm{O}$ into $\mathrm{I}_{2}(\mathrm{~g})$ and $\mathrm{O}_{0}$ on copper metal. ${ }^{18-21}$ Chinchen et al. ${ }^{11}$ reported that the Gibbs energies of $O($ ads) lormation on copper and cuprous oxide al $240 \mathrm{were}-240 \mathrm{~kJ} / \mathrm{mol}$ and $-130.5 \mathrm{~kJ} / \mathrm{mol}$, respectively. This indicates that the oxygen species adsorbed on a copper metal surface are more stable than those adsorbed on cuprous oxide. They suggested that oxygen adsorbed on copper acts as a promoter as well as a reaction 
intermediate, facilitating the chemisorption and subsequent dissociation of both water and carbon dioxide. If the interaction between adsorbent and adsorbate is strong. subsequent reaction to products would be slow: Therefore. $\mathrm{CO}$ is likely adsorbed on a removal oxygen ion rather than $\mathrm{Cu}^{\mathrm{i}}$. When copper is oxidized at reduced oxygen pressure below $200{ }^{\circ} \mathrm{C}, \mathrm{Cu}_{2-3} \mathrm{O}$ phase is formed, where $\mathrm{y}$ in $\mathrm{Cu}_{2-3} \mathrm{O}$ may have values up to $0.5 .^{12}$ Since the $\mathrm{Cu}_{-4} \mathrm{O}$ phase is metastable, it can be readily reduced by $\mathrm{CO}$. In fact. $\mathrm{Cu}_{2} \mathrm{O}$ is a good catalyst for the $\mathrm{CO}$ oxidation. while $\mathrm{CuO}$ is a good catalyst for the oxidation of $\mathrm{H}_{2}$ or light lydrocarbons. ${ }^{-2}$ The result enables us to consider a feasibility that $\mathrm{CO}$ reacts with oxygen ion fonned by the dissociation of $\mathrm{H}_{2} \mathrm{O}$ on copper metal site.

In this work. the reaction orders with respect to $\mathrm{CO}$ and $\mathrm{H}_{2} \mathrm{O}$ for the WGSR over the copper/zinc oxide catalyst were determined to be 0.79 and zero. respectively. The reaction order of 0.79 to $\mathrm{CO}$ in the present study is lower than the first order reported by Keiski $e t a l^{2}$ and Ovesen $e t a{ }^{2} .^{23}$ however it accords with that reported by Salmi et al ${ }^{\text {(i) }}$ The 0.79 -order to $\mathrm{CO}$ is believed to imply that an inhibition effect of $\mathrm{CO}_{2}$ is included in the reaction mechanism. Chinchen $e t$ $a l^{19}$ found that carbon dioxide was strongly chemisorbed on partially oxidized copper. indicating the inhibition effect of carbon dioxide. When the adsorption of $\mathrm{CO}$ on the active oxygen ion associated with copper is inhibited by $\mathrm{CO}_{2}$. the reaction order to $\mathrm{CO}$ would be lower than $\mathrm{l}$ as in the case of the present result. While the reaction order with respect to $\mathrm{H}_{2} \mathrm{O}$. zero-order. deviates somewhat from those of other investigators. ${ }^{-10}$ it is in accordance with that of Keiski $e t$ al. " The zero-order to $\mathrm{H}_{2} \mathrm{O}$ means that the catalyst surface is continuously saturated by $\mathrm{H}_{2} \mathrm{O}$ during the catalytic reaction. The apparent activation energies determined for the WGSR over the copper/zinc oxide catalyst is $50.9 \mathrm{~kJ} / \mathrm{mol}$ which is in agreement with $52.8 \mathrm{~kJ} / \mathrm{mol}$ reported by Keiski $e t$ al. ${ }^{\text {li' }}$

It is noted here that the present kinetic data for the initial reaction stage may be different from those for the stage showing a constant cataly tic activity after the initial reaction stage. Moreover the analysis was carried out generally from the data obtained up to 50 sec to provide the kinetic information for the early reaction stage. Conclusively: the PAS technique was believed to provide more precise kinetic informa- tion for the water gas shift reaction at a relatively clean surface of the catalyst. since the present experiments were conducted under the conditions of a relatively low reactor pressure and the initial stage characterized by high reaction rates.

Acknowledgment. This work was supported by grant No. 2000-2-12100-002-3 from the Basic Research Program of the Korea Science \& Engineering Foundation.

\section{References}

1. Grenoble, D. C.: Fstadt, M. M. $J$. C'atal 1981,67.90

2. Keiski. R. L.: Desponds. O.: Chane. Y. f'.: Somorjai. G. A. Appl. Catal. 1993. 101.317.

3. Rhodes. C.: Hutchings. G. I.: Ward. A. M. Catahsis Todkn 1995. 23,43

4. Kreuzer. I. B. hall (hem. 1978. 50. 597.

5. Joriecric, S.: Skenderi, S.: Ktijeric. N. Spect. Lett 1981, /f. 415

6. Choi. J. G.: Diebold. G. J. Anal. Chem. 1987.59.519.

7. Jung. H. J.: Lim. I. T.: Lee. S. H.: Kim. Y. R.: Choi. J. G. J. Phys. Chem. 1996. 100. 10243.

8. Kim, S. II.: Choi, J. G.: Cho, U. I. Rev! Sci. Instram 1998, 69 3.379

9. Kim, S. I.: Buun, I. S.: IJan. II. Y.; Ju, H. I..: I,e, S. II.: Choi. I. G. Appl. C'atal. A. Gemenat 2002. 234. 35.

10. Keiski. R. L.: Salmi. T.: Niemisto. P': Ainassari. J.: P'ohjola. V. J. Appl. Catal. At 1996. 137.349)

11. Chinchen, (i. C.: Speneer, M. S.J. Catal. 1988, //2.325

12. Kotstad. P. Wonstoichometry Iriffusion, and Electrical Conductwity in Binay Wetal Oxides: Wiley-Interscieno: Now York, 1972.

13. linkle. M.: Dumesic. I. A. J. Catal. 1987. 105.65.

14. Oki. S.: Mezaki. R. J. Plos. Chem. 1973. 77. 1602.

15. Bohlbro. H. An hasestigation on the Nimetics of the Comersion of (CO with Water Iapor over Inom Oxide Based ('atalsts: Topsoc. II.. F.d.: Gjellemp: Copenhagen. 1969.

16. Garbassi, F.: Petriti, G. J. C'atal. 1984. 90, 106.

17. Nakamura .t: Campbell. I. M.: Campbell. C. T. $J$. Chem. Soc. Faradlen Trams. I 1990. 86. 2725.

18. Campbell. C. T.: Duube. K. A. J. Caral 1987. J04. 109

19. Chinchen, G. C.: Spencer, M. S.: Waugh. K. C.: Whan. D. A. J. Chen. Soc. Forador Trans. $1987,83,2193$

20. Salmi, T.: I Iarakarainen. R. ippl Catal. . 1989. +9, 285 .

21. Campbell. J. M.: Nakamura. đ.: Campbell. C. T. J. Catal 1992. 1.36. 24

22. Cimino. A.: Carra. S. Electodes of Conductive Metallic Oxides. Trasatti, S., F.d.: FIscrier Sei.: New York, 1980; Chap. 2.

23. Oreson. C. V.: Clausen. B. S.: I Iammershoi, B. S.: Stettensen. C.: Askgard. T.: Chorkendortf. I.: Norskow: J. K.: Rasimussen, P. B.: Stoltze. P.: Taylor. P. J. Catal. 1996. 158. 170. 